\title{
温暖化適応策推進に資する既存施策の検討 一東京都を例として一
}

\author{
肱岡 靖明 1 岡 和孝 $2 \cdot$ 高野 真之 3 ・吉川 実 4 -市橋 新 5 \\ 1正会員 国立環境研究所 社会環境システム研究領域（†305-8506 茨城県つくば市小野川16-2） \\ E-mail:hijioka@nies.go.jp \\ 2非会員 みずほ情報総研株式会社＼cjkstart環境・資源エネルギー部（†101-8443 東京都千代田区神田錦町2-3） \\ E-mail: kazutaka.oka@mizuho-ir.co.jp \\ 3非会員 みずほ情報総研株式会社＼cjkstart環境・資源エネルギー部（テ101-8443 東京都千代田区神田錦町2-3） \\ E-mail: saneyuki.takano@mizuho-ir.co.jp \\ 4非会員 みずほ情報総研株式会社 環境・資源エネルギー部（†101-8443 東京都千代田区神田錦町2-3） \\ E-mail: minoru.yoshikawa@mizuho-ir.co.jp \\ 5非会員＼cjkstart東京都＼cjkstart環境局＼cjkstart環境政策部（†163-8001 東京都新宿区西新宿2-8-1） \\ E-mail: arata_ichihashi@member.metro.tokyo.jp
}

\begin{abstract}
温暖化による影響は世界各地で現れており，緩和策の強力な推進と共に，ある程度の悪影響が生じるこ とに備えて，長期的な視点で適応策を検討・実施することが早急に必要である。適応策を検討するにあた り，日本では，長く防災や環境管理，食料生産，国民の健康の保護のための対策を推進しており，それら は温暖化への適応策として効果を発揮する可能性があると考えられる．本研究では，適応策を講じるべき 対象分野・指標を網羅的に整理した上で，東京都を対象として適応策に資する既存の施策がどの程度存在 するかを調查した．結果，多くの分野および指標に対して，既存施策が適応策として有効に機能する可能 性があることが示された，さらに，自治体の適応策推進に向けた現状の課題を整理し，その問題点を改善 するために科学的知見をどのように活かす心゙きかについて解決案を提案した.
\end{abstract}

Key Words : climate change, impact assessment, adaptation measures, assessment report

\section{1. はじめに}

温暖化による影響はすでに現れており ${ }^{11}$, 今後，さら なる悪影響の加速が懸念されている. 今後20年程度は温 室効果ガスの削減程度にかかわらず温暖化が進むと予想 されている2). したがって, 緩和策 (温室効果ガスの排 出削減を行う対策）の強力な推進と共に，ある程度の悪 影響が生じることに備えて, 長期的な視点で適応策（気 候変動の影響に対し，その被害軽減を目的として講じる 対策）を検討・実施することが早急に必要である。しか しながら，緩和策の導入にあたっては，中長期的な目標 も含めて広く議論され，実行に移されつつあるが，適応 策に関しては，関係する国の法律はまだ制定されておら ず，非常に限られた自治体でのみ適応に関する規定がな されているにすぎないのが現状である゙．，一方，研究面 においては, Intergovernmental Panel on Climate Change
（IPCC）第四次評価報告書（AR4）の第二作業部会

(WG2) では一つの章でしか適応策について扱われな かったが1)，第五次評価報告書では四つの章で扱われる 予定である゙．また，日本においては，2010年度より開 始された 4 つの型研究プロジェクトを含む様々な分野 の研究が開始されつつある5,07,89.

温暖化が進行すると，その悪影響は長期間に及び，気 候安定化の効果が現れるにも長い時間を要する．そのた め, 将来の被害を可能な限り小さくし, 後世に対策の負 担を回さないようにするためには，今から長期的な視点 で適応策の検討・実施を考えておく必要がある，適応策 を検討するにあたり，日本では，長く防災や環境管理， 食料生産，国民の健康の確保のための対策を推進してお り，様々な施策や技術に関する多くの実績がある。これ らは温暖化一の適応策として効果を発揮寸る可能性があ ると考えられる. そこで, 本研究では, 自治体レベルで 
適応策を立案・実施していくにあたり，既存の施策が適 応策として資するかどうかについて整理し，科学的支援 はどのようにあるべきかについて提言することを目的と している．まず，適応策を講じるべき対象を網羅的に整 理した上で (第二章)，整理された対象事項に対して適 応策に資する既存の施策がどの程度存在するかを調査・ 整理し（第三章），次に，自治体において適応策を推進 するにあたり科学的知見をどのように活かすべきかとい う視点から現状の課題を整理してその解決策を提言し (第四章)，最後にまとめを述べた（第五章）。

\section{2. 適応策を講じるべき対象分野・指標の整理}

温暖化の適応策を検討するためには，温暖化による影 響を受ける分野および指標を明確にしておく必要がある。 しかしながら，温暖化によって影響を受ける分野や指標 は多岐に渡り, 網羅的に把握することは容易ではない。 そこで本研究では日本一の影響を中心に, 温暖化によっ て影響を受ける分野・指標を可能な限り網羅的に把握す ることを試みた。

まず，分野別の温暖化影響とその適応策に関して，専 門家により最も幅広く整理された国内の報告書「気候変 動への賢い適応（以後, 賢い適応）」9)を利用して, 対 象分野と指標を抽出し，分野・指標一覧表（表-1）を作 成した. ここで対象とする分野は, 気温や降水量変化, 海面上昇や台風強度の変化など, 気候の変化に関わるも のではなく, 人間活動に関わるものを基礎としている. 指標は分野の中でも, 気候の変動によって現状から有意 な変化が見込まれる事象を示している.

次に, 分野別の温暖化影響とその適応策に関して, 専 門家により最も幅広く整理された国際的報告書「IPCC

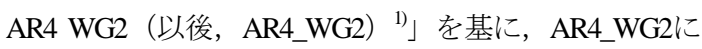
含まれており賢い適応に記載されていない情報を分野・ 指標一覧表に加えた．このとき，賢い適応とAR4_WG2 はほぼ同じような分野・指標を網羅していることがわか ったが，賢い適応の「国民生活・都市生活分野」では， 食料, 水環境・水資源, 自然生態系, 沿岸域・防災, 健 康の分野に含まれる指標と, AR4_WG2の「産業・居 住・社会」の分野に含まれている指標が混在していたた め, 本研究では, AR4_WG2の「産業・居住・社会」を 基に「社会システム」という分野を設定し, 他の分野と 重複しない項目と指標を整理した。このとき，日本を対 象とした整理を行ったため, 水河消失, 海面上昇による 島が沈む可能性, 砂漠化など, 明らかに日本に関連して いない指標は掲載していない.

最後に，作成された分野・指標一覧表の網羅性を検証 するために, 複数の国・州・都市レベルで公表されてい
る報告書10,111,12,133,14,151,16,17,181,192,20,21)を基に，対象として取り 上げられている分野・指標の抽出を行った. ここでは, 国・州・都市の行政が公式に出版し, 温暖化影響や適応 策に関する章が独立して記載されている報告書を選定し た. 記載されている分野および指標は, 章や節立てとし て記述されているものから, 数行で記載されているもの まで椂々であるが，本研究では記載内容の程度に関係な く, 関連事項が記載されているかどうかで判断した. 結 果, 今回対象とした報告書で取り上げられている分野・ 指標は, 分野・指標一覧表に関連づけることができた. 対象分野および指標の傾向を見ると, 都市を対象とした 報告書に比へ，国を対象とした報告書は分野・指標の網 羅性が高い，全体的な傾向としては，対象とする指標の 数は異なるものの, 水環境・水資源, 沿岸域・防災, 健 康, 社会システムの分野は, ほとんどの報告書に記載さ れていることがわかる。これは, 人間生活や社会システ ムへの直接的な影響の度合いについて関心が高く, 適応 策の重要度が高いと考えていると推察される.

対象とした報告書の数や質については, 今後さらに検 討する必要はあるものの, 温暖化による影響を受ける分 野および指標の収集, 整理, 検証を行い, 自治体レベル で影響評価および啇応策検討を実施する際の非常に有用 な基礎情報を確立することができた.

\section{3. 東京都を例とした既存施策の整理}

\section{(1) 既存施策の抽出}

現存する環境問題や社会的問題に対して，これまで 様々な施策が計画・実行されてきているが，1.で述べた ように，適応策に関してはこれから検討を始める段階で あり, 検討方法も確立していないため, その導入は容易 でないと推察される．検討方法のひとつとして，「気候 変動適応の方向性 ${ }^{22} 」$ の初動のステップ1に示されてい るように, 既存の施策・事業の中で適応策に関連寸るも のを整理することで, 適応策推進の可能性を検討するこ とは非常に有効かつ重要である. 適応策に関連寸る既存 の施策・事業に関する情報は「気候変動適応の方向性」 にも一部記載されている.

本研究では, より具体的に既存施策が適応策に資する かどうかを検討するために, 著者らが温暖化影響に関し て連携研究を行っている東京都を対象として, 表-1で示 す適応策を講じるべき対象と既存施策と, 既存施策に含 まれる個別対策の関連づけを行い，適応策に資寸るもの があるかどうかについて検討を行った，東京都では，既 存施策に対して適応策と明示していないものの，C40気 候変動東京会議等にて, 適応策となる可能性のある施策 を報告している23. 
表-1 日本国内に着目した温暖化影響・適応策を検討すべき分野・指標一覧

\begin{tabular}{|c|c|c|c|c|c|c|c|c|c|c|c|c|c|c|}
\hline & 分野 & 指標例 & $\begin{array}{l}\text { (シ) } \\
\text { 10) }\end{array}$ & $\begin{array}{l}\text { Aンバ } \\
\text { 11) }\end{array}$ & $\begin{array}{l}\text { マ|゙リ } \\
\text {-ト1'12) }\end{array}$ & $\begin{array}{l}\text { 下ロント } \\
\text { 13) }\end{array}$ & $\begin{array}{l}\text { ハシクー } \\
\text { バー14) }\end{array}$ & $\begin{array}{l}\text { 口゙イド } \\
\text { 15) }\end{array}$ & $\mid \begin{array}{l}\text { קンチI } \\
\text { スター16) }\end{array}$ & $N{ }^{17}$ & 独贵 & 瑞19) & 西登) & 伊光) \\
\hline \multirow{12}{*}{ 食料 } & \multirow{4}{*}{ 農業 } & [1] コメの収量, 品質 & & & & & & & & & \multirow{4}{*}{$\checkmark$} & \multirow{4}{*}{$\checkmark$} & \multirow{4}{*}{$\checkmark$} & \\
\hline & & [2] コメ以外穀物の収量，品質 & & & & & & & & & & & & $\checkmark$ \\
\hline & & [3] 果樹の生産適地分布, 生産量, 品質 & & & & & & & & & & & & $\checkmark$ \\
\hline & & [4] 茶・野菜の栽培地带区分, 収穫量, 品質 & & & & & & & & & & & & \\
\hline & \multirow{2}{*}{ 畜産業 } & [5]畜肉の産肉量 & & & & & & & & & $\checkmark$ & \multirow{2}{*}{$\checkmark$} & & $\checkmark$ \\
\hline & & [6] 飼料作物生産量 & & & & & & & & & & & & \\
\hline & \multirow{3}{*}{ 水産業 } & [7] 回遊魚の生息域（適水温海域） & & & & \multirow{3}{*}{$\checkmark$} & & & & & \multirow{3}{*}{$\checkmark$} & $\checkmark$ & $\sqrt{ }$ & \\
\hline & & [8] 沿岸性魚介藻類の漁場・生産力 & & & & & & & & & & $\checkmark$ & $\checkmark$ & $\checkmark$ \\
\hline & & [9] 養殖適地 & & & & & & & & & & & $\checkmark$ & $\checkmark$ \\
\hline & & [10] 工芸作物とバイオ燃料の土地利用競合 & & & & & & & & & $\checkmark$ & & & \\
\hline & その他 & [11] 農村地域の生計:自給農業と小規模農業 & & & & & & & & & & & & \\
\hline & & [12] 食料安全性 & & & & & & $\checkmark$ & & & $\checkmark$ & & & $\checkmark$ \\
\hline & & [13] 水量 & & & $\checkmark$ & & & $\checkmark$ & & $\checkmark$ & $\checkmark$ & $\checkmark$ & $\checkmark$ & \\
\hline 水環境 & 河川水 & [14] 水温・水質 & & & & $\checkmark$ & & $\checkmark$ & & $\checkmark$ & $\checkmark$ & $\checkmark$ & & \\
\hline & 湖㲽・ダい湖 & [15] 水量 & & & & $\checkmark$ & & & & $\checkmark$ & & $\checkmark$ & $\checkmark$ & \\
\hline & 湖沼・夕二湖 & [16] 水温・水質 & & & & $\checkmark$ & & $\checkmark$ & & $\checkmark$ & $\checkmark$ & $\checkmark$ & & \\
\hline 水資源 & 地下水 & [17] 水量 & & & & & & & & & $\checkmark$ & & $\sqrt{2}$ & \\
\hline & 地下水 & [18] 水温・水質 & & & & & & & & & $\checkmark$ & & & $\checkmark$ \\
\hline & & [19] 自然林分布・個体(群)数 & & & & & & & & $\checkmark$ & & $\checkmark$ & $\checkmark$ & \\
\hline & 森林生態系 & [20] 人工林分布 $\cdot$ 個体(群)数 $\cdot$ 公園 $\cdot$ 都市林 & & & & $\checkmark$ & $\checkmark$ & $\checkmark$ & $\checkmark$ & & $\checkmark$ & $\checkmark$ & $\checkmark$ & \\
\hline & & [21] 里山林等分布・個体(群)数 & & & & & & & & & & & & \\
\hline & 高山生態系 & [22] 分布適域・個体(群)数 & & & & & & & & & $\checkmark$ & $\checkmark$ & $\checkmark$ & \\
\hline & 淡水生態系 & [23] 分布・個体(群)数 & & & & & & & & & & $\checkmark$ & $\checkmark$ & \\
\hline & 湿原生態系 & [24] 分布適域・個体(群)数 & & & & $\checkmark$ & & $\sqrt{2}$ & & & $\checkmark$ & $\checkmark$ & $\checkmark$ & \\
\hline 自然 & 海洋生態系 & [25] 生物分布・個体(群)数 & & & & & & & & & $\checkmark$ & $\checkmark$ & & \\
\hline 日然 & & [26] サンココ礁・マングローブの分布・個体(群)数 & & & & & & & & & & & $\checkmark$ & \\
\hline 生態系 & 沿岸生態系 & [27] 干潟・藻場の面積, 生態系分布・個体(群)数 & & & & & & & & & 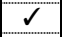 & & & \\
\hline & & [28] 砂浜生態系の分布・個体(群)数 & & & & & & & & & & & & \\
\hline & & [29] 植物季節変化 & & & & & & & & $\checkmark$ & $d$ & & $\checkmark$ & \\
\hline & & [30] 動物季節変化 & & & & & & & & & $\checkmark$ & & $\checkmark$ & \\
\hline & 複合領域 & [31] 生物多様性変化 & & & & & & $\checkmark$ & & $\checkmark$ & $\checkmark$ & $\checkmark$ & $\checkmark$ & $\checkmark$ \\
\hline & & [32] 複数生物群系にまたがる影響 & & & & & & $\checkmark$ & & & & & & \\
\hline & & [33] 土壤生態系の構成・個体群 & & & & & & & $\checkmark$ & & $\checkmark$ & & $\checkmark$ & \\
\hline & & [34] 高潮浸水 & $\checkmark$ & $\checkmark$ & & & & $\checkmark$ & & $\checkmark$ & $\checkmark$ & & $\checkmark$ & $\checkmark$ \\
\hline & 沿岸域 & [35] 海岸浸食 & & $\checkmark$ & & & $\checkmark$ & & & $\checkmark$ & & $\checkmark$ & & $\checkmark$ \\
\hline 沿岸域 & & [36] 砂浜消失 & & & & & & & & & & & & \\
\hline 㐰)干域 & & [37] 内水氾濫 & & & & & $\sqrt{ }$ & $\checkmark$ & & $\checkmark$ & $\checkmark$ & $\checkmark$ & & \\
\hline 防桨 & 河川 & [38] 外水氾濫 & $\checkmark$ & & $\checkmark$ & $\checkmark$ & & $\checkmark$ & & $\checkmark$ & $\checkmark$ & $\checkmark$ & & \\
\hline & & [39] 土砂災害 & & & & & & & & & & $\checkmark$ & & $\checkmark$ \\
\hline & 土砂 & [40] 土砂流出量 & & & & & & & & & & & & \\
\hline & 熱ス卜 & [41] 死亡数・熱中症搬送数 & $\checkmark$ & & $\checkmark$ & $\sqrt{ }$ & & $\checkmark$ & $\checkmark$ & & $\checkmark$ & $\checkmark$ & $\sqrt{ }$ & $\checkmark$ \\
\hline & 熱大下レス & [42］睡眠障害 & $\checkmark$ & & & & & & $\checkmark$ & & & & & \\
\hline & & [43] 水系感染症 & $\checkmark$ & $\checkmark$ & $\checkmark$ & $\checkmark$ & & $\checkmark$ & & & & $\checkmark$ & $\checkmark$ & $\checkmark$ \\
\hline & 感染症 & [44] 食品を介した感染症 & & & $\checkmark$ & $\checkmark$ & & & & & $\checkmark$ & $\checkmark$ & $\checkmark$ & $\checkmark$ \\
\hline 健康 & & [45] 動物媒介感染症 & $\checkmark$ & $\checkmark$ & $\checkmark$ & $\checkmark$ & & $\checkmark$ & & & $\checkmark$ & $\checkmark$ & $\checkmark$ & $\checkmark$ \\
\hline & & [46] 自然災害 & & $\checkmark$ & & & & $\checkmark$ & & & & $\checkmark$ & $\checkmark$ & \\
\hline & その他 & [47] 大気污染 & & & $\checkmark$ & $\checkmark$ & & $\checkmark$ & & & & $\checkmark$ & $\checkmark$ & $\checkmark$ \\
\hline & & [48] アレルギー & & & $\checkmark$ & & & $\checkmark$ & & & $\checkmark$ & $\checkmark$ & & \\
\hline & & [49] 住宅等への影響 & $\checkmark$ & $\checkmark$ & & & & $\checkmark$ & $\checkmark$ & & & $\checkmark$ & & \\
\hline & 生活 & [50] 収入の変化 & $\checkmark$ & $\checkmark$ & & & & $\checkmark$ & & & & $\checkmark$ & $\checkmark$ & \\
\hline & & [51] 快適性の変化 & & & & & & $\checkmark$ & $\checkmark$ & & & & $\checkmark$ & \\
\hline & 文化・歴史 & [52] 観光資源・文化財への影響 & & & & & & & & & & & $\checkmark$ & \\
\hline & 全業 & [53] リンケージインフラ, 投入源の変化 & $\checkmark$ & $\checkmark$ & & $\checkmark$ & & & & & $\checkmark$ & & & \\
\hline & & [54] 貿易への影響 & & & & $\checkmark$ & & & & & $\checkmark$ & & & \\
\hline 社会 & & [55] 小売および商業サービスへの影響 & $\checkmark$ & $\checkmark$ & & & & & & & & $\checkmark$ & & \\
\hline シス & & [56] 保険への影響 & & & & & & $\checkmark$ & & $\checkmark$ & $\checkmark$ & & $\checkmark$ & \\
\hline テム & & [57] 観光, レクリエーションへの影響 & & & $\checkmark$ & $\checkmark$ & & & $\checkmark$ & & $\checkmark$ & $\checkmark$ & $\checkmark$ & $\checkmark$ \\
\hline & & [58] 給水能力の変化 & $\sqrt{5}$ & $\checkmark$ & $\checkmark$ & $\checkmark$ & $\sqrt{ }$ & $\checkmark$ & & $\checkmark$ & & $\checkmark$ & $\checkmark$ & $\checkmark$ \\
\hline & 公共事業 / & [59] 輸送インフラへの影響 & $\checkmark$ & $\checkmark$ & & $\checkmark$ & $\checkmark$ & $\checkmark$ & $\checkmark$ & $\checkmark$ & $\checkmark$ & $\checkmark$ & $\checkmark$ & \\
\hline & 公兵事莱／ & [60] エネルギー(電力・ガス)インフラへの影響 & $\checkmark$ & $\checkmark$ & & $\checkmark$ & & $\checkmark$ & & $\checkmark$ & $\checkmark$ & $\checkmark$ & $\checkmark$ & \\
\hline & & [61] 通信インフラへの影響 & & & & $\checkmark$ & & & $\checkmark$ & $\checkmark$ & & $\checkmark$ & & \\
\hline & & [62］衛生環境（都市排水等）の悪化 & $\checkmark$ & & & $\checkmark$ & & & & $\checkmark$ & & & & \\
\hline & 社会問題 & [63] 社会状況の変化 & & $\checkmark$ & & $\checkmark$ & & & & & & & & \\
\hline
\end{tabular}


適応策に関連する既存施策を抽出するために，a)〜c) の手順で作業を行った.

a) 東京都の事業概要, 各種事業計画書および部局の $\mathrm{HP}$ 等を基に内容を確認し，表-1 に整理した各分野・指 標に関連寸る施策を抽出した.

b) 環境省作成の熱中症環境保健マニュアルや，国交 省・東京都・その他地方自治体が合同で計画した鶴見川 流域水害対策のように東京都が策定していない，もしく は東京都が主とならないが，東京都に関係が深い各種施 策を検索し，a) と同様に表-1 に整理した各分野・指標に 関係がある施策を抽出した.

c) a),b)により抽出された既存施策を，東京都環境局職 員も含めて複数回確認し精査した。

既存施策の抽出においては，定量的・定性的施策のい ずれも対象とし，定量的な施策に関しては，施策の達成 目標年と具体的な目標を整理した. 施策の抽出において は，(1)表-1で示される分野・指標一覧表の各指標例に 対して直接関係する施策か, (2)直接的な施策でなくとも, 間接的な効果があると考えられる施策かどうか（例えば, 影響への対策を実施する際に基礎情報となりうる要素

（気温，降水，水位，大気污染物質など）の観測情報蓄 積，発生した影響に対する補償，水害，土砂災害や健康 被害などの発生要因となる降水の表面流出や大気污染物 質の排出量などを緩和・軽減させる可能性のある施策か 否か，防災訓練や救助体制の確保など影響被害の悪化軽 減に寄与寸るか否か，など）という視点から判断した. なお，抽出した具体的な施策は，整理のために必ずしも 正式名称で記載されてはいないことに留意されたい.

前述した施策の抽出方法においては以下の問題がある. 事業計画では想定外の災害への対応が将来の適応策とな りうる場合には, 事業概要から読み取ることはできない. また，各部局が独自に実施している内部資料用の非公開 研究は，事業概要などからでは抽出ができない，そのた め本研究では, これら入手が困難な情報については対象 外とした. 関連する分野・指標の判断が難しかった例と しては，健康分野の指標「大気污染」における自動車等 からの排気ガス削減に関連する施策（交通局，中央卸売 市場，環境局）が挙げられる。これは，施策による排出 ガス減少の効果規模について考えた際，環境局や交通局 は比較的大きな効果があると考えられるが，中央卸売市 場は場内車両対象の施策なので市場内のごく小さな範囲 にしか効果を及ぼさないと考えたからである。 今回は施 策効果の大小について考慮せずに抽出することとした.

表-2 に結果を示寸，農業など多くの分野において， 同一分野における個別指標ごとに施策を分類することは 難しい. これは特定の指標のために策定された施策ばか りでなく，より包括的な施策として策定されているため である。このような場合，複数の指標に関係する施策と
考え，表-2では必ずしも指標別の施策分類ではなく， 例えば，農業分野の全ての指標に共通する施策とした.

工夫した点としては，相互に連携していると考えられ る部局は互いの事業概要およびHPの確認を行い，双方 に記載がある場合に連携しているという判別を行った

（「都市整備局・建設局」）。また，「熱ストレスによ る死亡」については直接の記載が見つからなかった。 そ のため，熱中症環境保健マニュアル（環境省） ${ }^{24} に$ に用 いられている「熱中症」，寸なわち「暑熱障害による症 状の総称」が「熱ストレスによる死亡」にも当てはめら れるものと考え施策の抽出を行った.

結果より，適応策に資する施策とそれに含まれる定量 的な目標は少ないものの，既に行っている事業から抽出 される個別施策は，ほぼすべての分野・指標に関連づけ られることが明らかとなった。

\section{(2) 既存施策の類型化と今後の展開}

適応策として機能する可能性が示唆された施策は大き く分けて次の 3 つ分類できる

a) 単一の指標のみに抽出できるもの（『砂防ダムの整 備等』, 『野生動植物保護』など)

b) 同一分野にて横断的に整理できるもの（『漏水対 策』：「水環境・水資源」分野の指標「水量」に関係寸 る渴水影響に対して共通して効果がある（地下水は除

く）。『リアルタイム降水情報の提供』：「沿岸域・防 災」分野の内水汇濫，外水汇濫，土砂災害等の発生予察 に効果がある。『都税の減免・猶予制度』：「沿岸域・ 防災」分野の風水害被災後に効果がある，など）

c) 分野横断的に整理できるもの（『水道水源林の管 理』:「水環境・水資源」分野に共通寸る指標「水量」 および「自然生態系」分野の森林生態系の指標「自然林 分布・個体 (群) 数」-「人工林分布 - 個体 (群) 数 公園・都市林」 -「里山林等分布・個体 (群) 数」の両 分野の指標に効果がある。『スギ林の広葉樹への転 換』：「自然生態系」分野の森林の平準化に関係する指 標「自然林分布・個体（群）数」-「人工林分布 - 個体

(群) 数 - 公園 - 都市林」 -「里山林等分布 - 個体

(群) 数」および「健康」分野の花粉症患者減少に関係 する指標「アレルギー」の両分野に効果がある，など）

a)から c)に向かうにつれ，1つの施策がより多くの指 標と関係するため，適応策に資する施策としては汎用性 が高いと考えることができる，しかしながら，汎用性が 高い可能性がある施策であっても，1部局のみではその 有用性，関係性がわかりにくいと考えられる，適応策に 資する施策を十分に活か寸ためには，各施策が有する複 数の影響への効果（施策と影響の関係性）を各部局が認 識し，影響指標ごとに部局ごとの役割および施策の範囲 を整理する必要があると考えられる。 
表-2 東京都を対象とした温暖化影響とその対策として関連する既存政策の整理

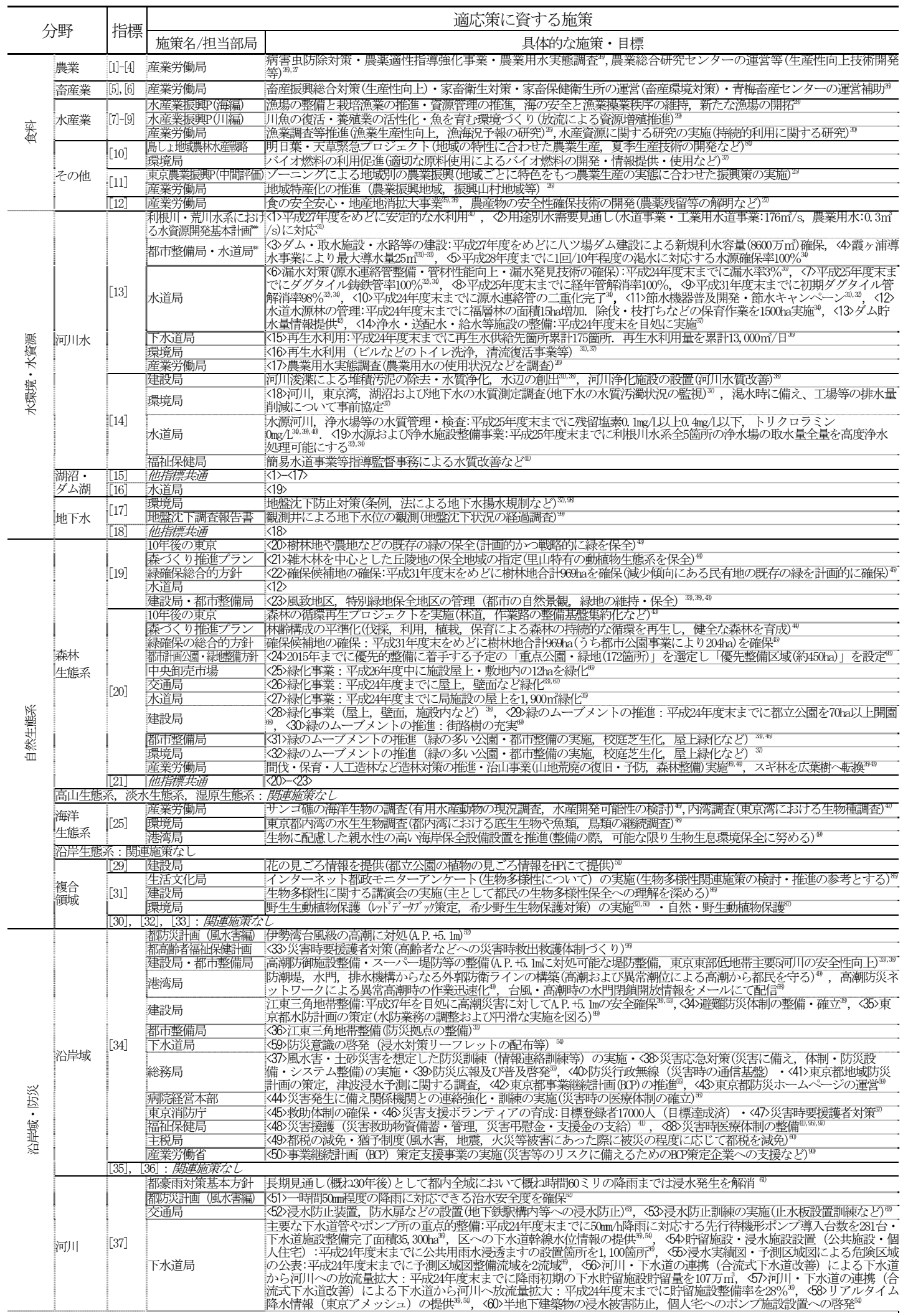




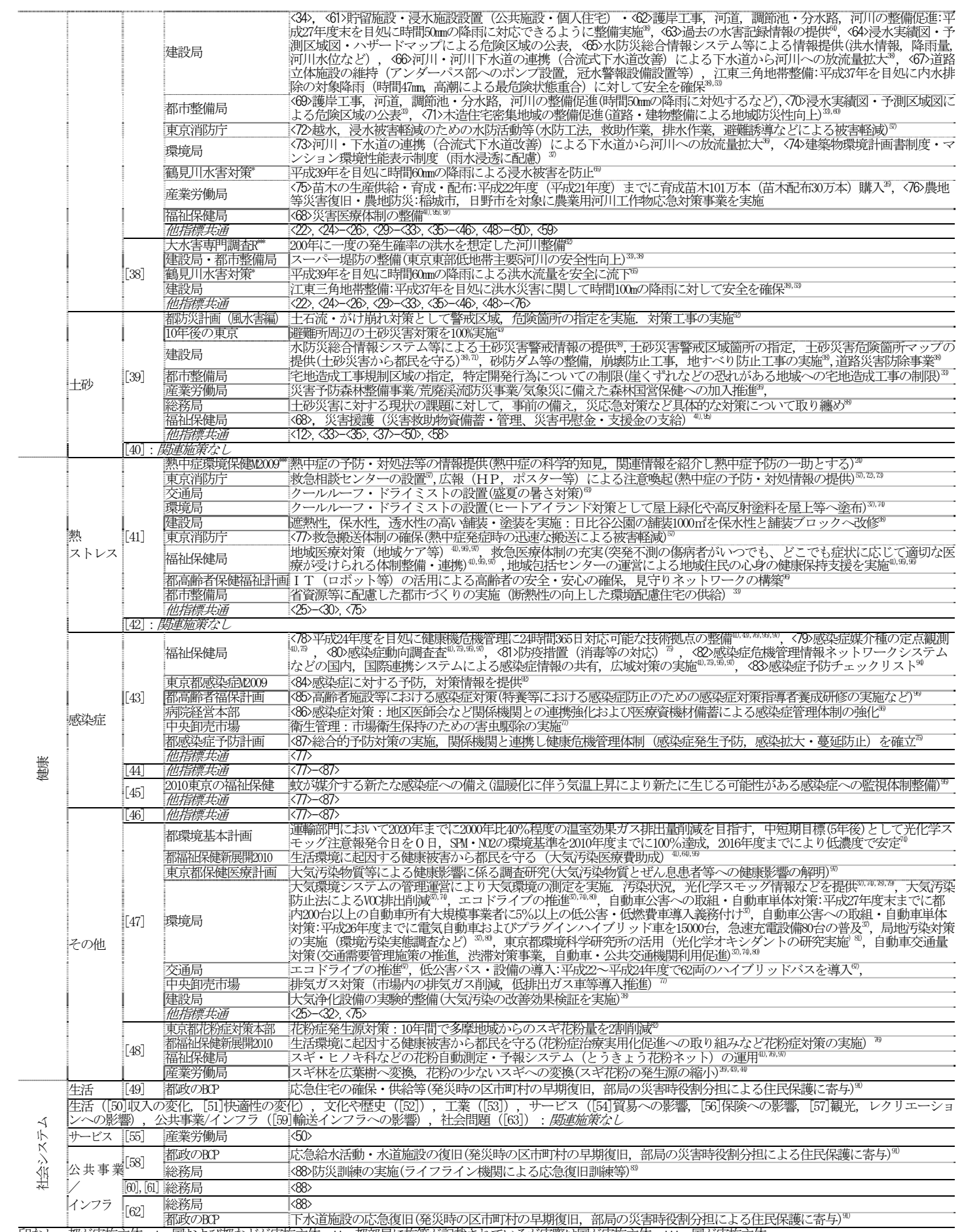

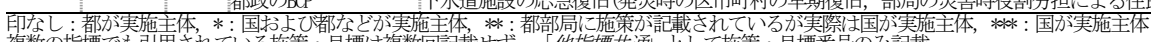

複数の指標でも引用されている施策・目標は複数回記載せず,「他指標共通しとして施策・目標番号のみ記載.

今後の展開として，(1)現状では気候変動の影響をリス ク要因と捉えた施策の検討は行われていないので, 気候 変動を加味した既存施策を将来的に見直し，(2)その検討 をスムーズに進めるために情報の共有化に取り組み, (3) 既存施策の範疇で対応ができない場合，新たな施策の検
討を行う，という手順が考えられる.

(1)については，既存施策の多くが将来的な気候変動を 加味せずに策定されているため, 現時点では非常に効果 的に作用する施策も, 30 年後, 50 年後の将来の気候変 動については対処ができない可能性があると考えられる 
例として，効果が現れるまでに時間を必要とする「沿岸 域・防荻」分野（堤防整備等），「自然生態系」分野

(森林保全等)，「水資源・水環境」分野（ダム整備・ 水道水源林整備等），「食料」分野（果樹の生産適地分 布等）などは，影響が表面化してからの立案では，対策 が間に合わない可能性がある，そのため，施策を見直す 際には，気候変動を加味した施策の策定が必要と考えら れる. (2)にいては, 部局間のデータ・情報・研究成果 の共有化がなされていることで迅速な適応策の立案・実 施が可能となると考えられる．また，福祉保健局が実施 している施策「感染症健康危機管理情報ネットワーク」 のように, 都部局間のみならず, 官公庁・外部研究施 設・諸外国関係機関と連携し，組織的に情報を蓄積する ことでより正確かつ迅速な政策立案が可能となると考え られる. (3)については, ゲリラ豪雨など現象自体が十分 に解明されておらず, 将来温暖化に伴って変化する可能 性のある課題に対する検討などが考えられる。

\section{4. 自治体の適応策推進に向けた科学的支援に関 する検討}

\section{(1) 適応策推進に向けた課題}

3.で示したように，東京都においては多くの既存施策 が適応策として機能する可能性が示された。これは，他 の自治体においても同様な施策が講じられており，既存 施策を適応策に展開できる可能性があると考えられる. しかしながら，適応策の検討は今まさに始まったばかり のため, 今後, 将来の温暖化の進行程度を考慮しながら, 具体的な目標時期と定量的な対策レベルを決定するにあ

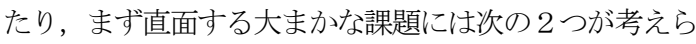
れる.

課題 1 : 適応策を実施した経験もなく, 検討方法も確 立されていないため，何から始めればいいのか，何をど うすればよいかわからない状況にあること。

課題 2 : 自治体レベルを対象とした温暖化の将来影響 や適応策の定量的評価に関しても, 研究が開始されたば かりのため, 適応策検討を支援するための科学的知見も そしい状況にあること。

\section{（2）適応策策定のためのガイドライン作成の必要性と 課題}

課題 1 を解決するため必要な科学的支援として，適応 策策定のためのガイドライン作成が挙げられる.「気候 変動適応の方向性」ではその大枠が示されているが, 自 治体において適応策を推進寸るためには，既存施策の有 効活用を推進し, 自治体自ら実行可能で実践的なガイド ラインの作成が急務である.
温暖化による影響評価および適応策の検討に関しては, 一般的な環境影響評価とは異なり，将来の気候および社 会経済シナリオと，それに伴う不確実性を考慮しなくて はならない.さらに, 定量的な影響評価から得られた結 果の不確実性の解釈も容易ではない，したがって，不確 実性を含む科学的な知見をどのように適応策の計画・実 施に組み込むかについての情報をガイドラインに示す必 要がある，科学の不確実性を施策に活か寸ためには，テ

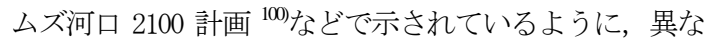
る対象年，異なる気候シナリオ，確率を持った結果を併 記した上で，気候変動の進行具合によって対策を選べる ように, 複数の代替案を準備しておくことが重要である. このような不確実性の情報付与と理解, 利用方法には研 究者による支援が必須となる。このとき, ガイドライン を作成する研究者は, 利用する行政担当者に科学的知見 の限界も含めて利用方法を伝える（コミュニケーショ ン）努力も必要となる。

\section{（3）自治体レベルでの影響評価実施の推進}

課題 2 を解決するためには，自治体レベルを対象とし た温暖化の将来影響や適応策の定量的評価を推進してい く必要がある.このとき, 施策立案のためにどの程度の 空間・時間解像度でどれぐらいの精度を持った定量的評 価結果が必要であるか, 研究的側面から定量的な評価手 法にはどのようなものがあるか，また，評価手法の有す る空間・時間解像度, 最新の知見と科学的限界を整理し ておく必要がある.

新たな研究成果や手法の開発がこれから期待されるが, より効果的に研究を進めるためには，11行政側において, 施策や対策検討のためにこれまで実施した評価結果に関 連する資料を一元的に整理しておくこと, (2)研究者側に おいて自治体レベルで実施可能な影響評価モデルに関す る情報を一元化しておくことが肝要である.

(1)に関しては，これまで実施した評価結果（モデル， データ，報告書など）を蓄積しておくことにより，新た な評価手法の開発や既存手法を用いた再計算を迅速に行 うことが可能となる. 特に, 大学や研究所と連携するに あたり，自治体が保有するデータおよび既存関係資料を 積極的に活用できるようにして，研究活動を後押しする ことは有効である. 従来, データおよび関係資料の目的 外利用は想定されておらず，その利用に関しては厳しい 審查と制限付きの許可が一般的であり, 研究者が自由に データを利用できる状況にない場合がほとんどである. また，利用に際して申請の手続きが煩雑である. 行政と 研究者の間でさらに協働の実績を積み上げることにより， 信頼関係の一層の向上を図ることで，審査の簡素化，制 限の緩和を推進し，連携を高めることができると考えら れる. データ自体に関しては, 部局別に管理されている 
場合が多いが，3.(2)(2)で挙げたとおり，部局間のみなら ず研究機関を含めた関係各所との情報の共有化が重要で ある．特に，データ管理の効率性を高めるために部局を 越えた共通データベースを確立し管理することが望まれ る．現在，研究者がデータを利用する場合，どのような データが管理され利用可能であるかを調べることから始 めなくてはならず，非効率である．また，提供する側の 行政も適応策の様に分野横断的な課題に対応する場合, 部局間のデータ収集や提供手続きのためのマンパワーと 時間削減のために，このようなデータベースが構築され ると施策立案のための研究を効率よく行うことができ, 研究者, 行政双方にとって有益であると考えられる. な お，このデータベースの管理に関しては，自治体の研究 所や国と連携することが考えられる.

(2)に関しては, 国の大学や研究所等の研究者が, 様々 な手法やモデルを開発しているものの，その情報が一元 化されていないため, 行政側としてはどのような指標を 定量的に評価できるか把握することが困難である.よっ て, 指標別に, 研究機関・研究者, モデル概要, 入力デ ータ（データの種類，空間・時間解像度、入手先）, 必 要な気候シナリオ (気候パラメータ, データの空間・時 間解像度、入手先），必要な社会経済シナリオ，そして 影響評価モデルによって算出される具体的な出力データ （データの意味，精度，不確実性）などに関寸るデータ ベースの開発が必要である. なお、データベースの操作 性，およびそこに記載されている内容については，その 利用方法に鑑みると，行政側にとっても可能な限り理解 の容易なものであることが望まれる.

\section{5. まとめ · 今後の課題}

本研究の結果, 以下の成果が得られた.

(1) 国内外の科学的報告書および海外の国・州・都市別 報告書に基づき，適応策を講じるべき対象分野・指 標を網羅的に整理した.これによって，自治体レべ ルで影響評価および啇応策検討を実施する際の非常 に有用な基礎情報を確立することができた.

(2) 東京都を対象として, 既存施策が温暖化により影響 を受ける分野および指標と関連づけられるか検討し た結果，多くの分野および指標において既存施策が 適応策に資する可能性があることが明らかとなった。 これは，他の自治体でも同様であると考えられ，日 本全体において適応策を効果的に推進できる可能性 が高いと考えられる.

(3) 自治体の適応策推進に向けた課題と課題解決に向け た科学的支援に関して考察を行い，ガイドライン作 成の重要性と自治体レベルでの影響評価推進に関し
て提言を行った.

適応策の検討に関しては, 今, まさに始まったばかり であり，新たな課題として必ずしも認知されていないた め, 適応策の計画・実施に関わる予算の措置は容易では ないと考えられる. しかしながら，本研究で明らかにな ったように，既存の施策立案・評価の際に将来の温暖化 影響も考慮しておくことで, 新たに施策を検討する必要 がなく, 追加的な費用も極力抑えることが可能になる.

既存施策の中から，特に重点を置くべき分野・施策を 判断する基淮について, 今後の課題(1)て挙げた気候変動 を加味した既存施策の将来的な見直しという視点から以 下の三タイプに分類して考えることを提案する. (1)将来 の気候変化による影響被害予測を基に対応を検討すべき タイプの施策，(2)気候变動状況に合わせて対応を検討寸 ベき施策，(3)既に適応策として機能しているタイプの施 策. (1)は長期的に計画をしなければ影響被害を防ぐこと ができなくなる可能性があるもの（防災分野の堤防建設 など），(2は長期的な計画を必要とせず, 状況に応じて 施策を変化させていくべきもの（防災訓練や健康危機管 理センターなど），(3は一度策定すれば特に追加施策が 不要なもの（降水量や河川水位など防災情報の提供な ど）である. (1)>(2)>(3)の順に施策の検討の際に気候変 動の影響を考慮する必要がある.この分類は, どの分野, どの施策から検討を始めるべきかという優先順位の目安 となりうる.

施策検討には，将来の影響をどの程度考慮しておくか， 適応策をいつどの程度導入するか, 将来の社会経済の変 化をどこまで加味するかなどについての検討が必要であ り, 人間活動・社会・環境問題を総合的に取り扱う環境 システム研究的アプローチの推進が今後求められる.

謝辞 : 本研究は, 東京における気候変動の影響に関する 連携研究および環境省の環境研究総合推進費 (S-8) の 支援により実施された。ここに記して謝意を表する.

\section{参考文献}

1) IPCC, 2007: Climate Change 2007: Climate Change Impacts, Adaptation and Vulnerability. Contribution of Working Group II to the Fourth Assessment Report of the Intergovernmental Panel on Climate Change, Cambridge University Press, Cambridge, United Kingdom and New York, NY, USA

2) IPCC, 2007: Climate Change 2007: The Physical Science Basis. Contribution of Working Group I to the Fourth Assessment Report of the Intergovernmental Panel on Climate Change, Cambridge University Press, Cambridge, United Kingdom and New York, NY, USA.

3）田中充, 白井信雄, 小河誠, 木村浩巳 : 地球温煖化による地域への 影響・適応策への取組み実態調查 (文献調查) の結果の概要, 法政 ニュースリリース, 2011.

http://www.hosei.ac.jp/hosei/koho/newsrelease/054.html

4) IPCC : Outline of the Working Group II Contribution to the IPCC Fifth Assessment Report, http://www.ipcc-wg2.gov/AR5/ar5-outline.html 5) 環境省総合環境政策局・地球環境局: H22年度環境研究総合推進費, 
pp.12，環境省，http://www.env.go.jp/houdou/gazou/12772/s-8.pdf

6) 文部科学省 : 気候変動適応研究推進プログラム, 気候変動適応研究 推進プログラム事務局, http://www.mext-isacc.jp/

7) 農林水産省 : 農林水産分野における地球温暖化対策のための緩和及 び適応技術の開発，進行調整費

8) 科学技術振興機構 : 平成22年度新規採択課題一覧「気候変動に対応 した新たな社会創出に向けた社会システム改革のプログラム，文部 科学省, http://www.jst.go.jp/shincho/press_h22.html

9）環境省地球温暖化影響・適応研究委員会 : 気候変動への賢い適応一 地球温暖化影響・適応研究委員会報告書一賢い適応，環境省，2008

10) Panya Consultants Co., Ltd.,; Climate Change Impact and Adaptation Study for Bangkok Metropolitan Region, Final Report, 2009. http://issuu.com/worldbank.eastasiapacific.sd/docs/climatechangebangkokmainreport

11) Patankar, A., A. Patwardhan, J. Andharia and V. Lakhani: Mumbai City Report, International Workshop on Climate Change Vulnerability Assessment and Urban Development Planning for Asian Coastal Cities, 2010. http://cc.start.or.th/climateChange/Document/Doc_eng_16.pdf

12) City of Madrid: City of Madrid Plan for the Sustainable Use of Energy and Climate, 2008. http://www.c40cities.org/docs/ccap-madrid-110909.pdf

13) City of Toronto: Ahead of the storm: Preparing Toronto for Climate Change - Development of a Climate Change Adaptation Strategy, Toronto Environment Office, 2008. htttp://www.toronto.ca/teo/pdf/ahead_of_the_storm.pdf

14) City of Vancouver: Climate Change Adaptation - Administrative Report, 2008. http://vancouver.ca/sustainability/documents/7193ClimateAdaptationReport27May2008.pdf

15) Greater London Authority: The draft climate change adaptation strategy for London: Public Consultation Draft, 2010.

http://www.london.gov.uk/climatechange/sites/climatechange/staticdocs/Cli miate_change_adaptation.pdf

16) Lawson, N. and J. Carter: Greater Manchester Local Climate Impacts Profile (GMLCIP) and assessing Manchester City Council's vulnerability to current and future weather and climate, University of Manchester, 2009. www.sed.manchester.ac.uk/architecture/research/ecocities/library/document s/GMLCLIP.pdf

17) Rosenzweig C. and W. Solecki: Climate Change Adaptation in New York City: Building a Risk Management Response. New York City Panel on Climate Change 2010 Report, Annals of the New York Academy of Sciences, 1196, 2010.

http://onlinelibrary.wiley.com/doi/10.1111/nyas.2010.1196.issue-1/issuetoc

18) The Federal Government: German Strategy for Adaptation to Climate Change, 2008.

http://www.bmu.de/files/english/pdf/application/pdf/das_gesamt_en_bf.pdf

19) Swedish Commission on Climate and Vulnerability: Sweden facing climate change - Threats and opportunities, 2007. www.regeringen.se/content/1/c6/09/60/02/56302ee7.pdf

20) Spanish Ministry of the Environment and Rural and Marine Affairs: PNACC - The Spanish National Climate Change Adaptation Plan, 2008. http://www.mma.es/secciones/cambio_climatico/documentacion_cc/divulga cion/pdf/pnacc_ing.pdf

21) WHO Regional Office for Europe: Environment and health risks from climate change and variability in Italy, 2007. http://www.euro.who.int/_data/assets/pdf_file/0007/95920/E90707.pdf

22) 気候変動適応の方向性に関寸る検討会: 気候変動適応の方向性, 環境省, 2010 . http://www.env.go.jp/earth/ondanka/adapt_guide/pdf/approaches_to_adaptation.pdf

23) $\mathrm{C} 40$ 気候変動東京会議事務局 : C 40 気候変動東京会議2008報告書, 東京都, 2008.http:/www.c40toky0.jp05.html

24）環境省: 熱中症環境保健マニュアル 平成21年6月改訂, p. 60, 環境省, 2009.

25) 東京都: 東京農業振興プランの中間評価と今後の地域別取組 平成18年6月, pp. 9, 31,33-52, 東京都, 2001.

26) 東京都産業労働局: 事業概要 平成22年版, pp. 98-103,107-112,119, 東京都産 業労働局, 2010.

27) 東京都農林総合研究センター: 東京都農林総合研究センターホームページ
「研究課題」, http:/Www.tokyo-aff.or.jpcenterkenkyusyokaiO2index.html

28) 東京都: 水産業振興プラン (海編) 平成21年3月, p.8, 東京都, 2009 ,

29) 東京都: 水産業振興プラン (川編) 平成18年3月, p.4, 東京都, 2006.

30) 東京都島しょ農林水産総合センター: 東京都島しょ農林水産総合センターホ ームページ「水資源の持続的利用に関寸る研究」, http://www.ifarcmetro.tokyo.jp25,1290,39.html,

31) 国土交通省 : 国土交通省ホームページ「根川水系およひ䐠川水系における水 資源開発基本計画の変更について」, htp!/www.mlitgo.jplcommon000018926.pdf

32) 東京都水道局: 事業概要 平成22年版, pp.19,50,52,58,79, 東京都水道局, 2010.

33) 東京都都市整備局: 事業概要 平成21年版, pp.130,138,142,144,152,162,172,177, 229-230，東京都都市整備局，2009.

34) 東京都水道局: 東京水道経営プラン 2010 平成22年1月，pp.3,15,21,25-26, 東 京都水道局, 2010

35) 東京都水道局 : 東京都水道局環境計画2010-2012 平成22年3月, pp.8,10-11, 東 京都水道局, 2010

36) 東京都下水道局: 東京都下水道事業 経営計画2010 平成22年2月，pp.6,25,29, 33,48,77, 東京都下水道局, 2010.

37) 東京都環境局 : 事業概要 平成21年版, pp.43,48,63,67,73-79,83-87,119-120,122125,128,132,134,144，東京都環境局，2009.

38) 東京都建設局 : 事業概要 平成21年版, pp.56,58,63,79-84,88-89,91,93,109,122, 177, 東京都建設局, 2009.

39）東京都水道局 : 東京都水道局ホームページ「水質検查結果」, http:/www.waterworks.meto.tokyo.jp/water/w_infos__kekkahtml

40) 東京都水道局 : 平成22年度水質検查計画, p.20, 東京都水道局, 2010 ,

41) 東京都福祉保健局: 事業概要 平成21年版, pp.163-164,180,285,306-308,311, 319-320,324-326, 東京都福祉保健局, 2009。

42) 東京都水道局: 東京都水道局ホームページ「ダム貯水量」, http:/www.waterworks.metro.tokyo.jp/waterssuigen.html,

43) 東京都：「10年後の東京」への実行プログラム2010 平成22年12月, pp.14,1718,82, 東京都, 2010

44) 東京都: 森づくり推進プラン 平成21年3月, pp.25-27,65, 東京都, 2009,

45) 東京都: 緑確保の総合的な方針 平成22年5月, pp.31,33,41, 東京都, 2010.

46) 米山純夫, 妹尾浩太郎, 前田洋志, 小埜田明, 林原毅 : 沖ノ鳥島サンコ礁の 海洋生物，東京都水产海洋研究報告，pp.7385, 2006.

47) 東京都島しょ農林水産総合センター: 東京都島しょ農林水産総合センター ホームページ「東京湾便り」, http://www.ifarcmetr.tokyo.jp/22,297,47.hml

48) 東京都環境局 : 東京都環境局ホームページ「東京都内湾の水生生物調查結 果」, http:/www.kankyo.metro.tokyo.jp/watertokyo_bay/creatureaquatic_creaturehtoml

49) 東京都港湾局: 事業概要 平成21年版, pp.108-109, 115, 東京都港湾局, 2009.

50) 東京都環境局 : 東京都環境局ホームページ「レッドデータブック」， http://www.kankyo.metro.tokyo.jpinature/animals_plants/rire_creatureired_data_bookindex.html

51）東京都建設局 : 東京都建設局ホームページ「都立公園花の見ごろ情報」， http:/www.kensetsumetro.tokyo.jpkouenhananomigoroindex.html

52) 東京都防㷋会議: 東京都地域防災計画風水害編 平成19年, pp.27, 45,50-54, 東京都防災会議，2007.

53) 東京都: 荒川水系江東内部河川整備計画 平成17年9月, pp22-23, 東京都, 2005.

54) 東京都下水道局: 事業概要 平成22年版, pp.31,37, 東京都下水道局, 2009.

55) 東京都総務局 : 事業概要 平成22年版, pp.91-94, 97, 102, 東京都総務局, 2010.

56) 東京都病院経営本部: 事業概要 平成22年版, pp.49, 東京都病院経営本部, 2010.

57) 東京消防庁 : 消防行政の概要 平成22年，pp.24,28,33,39-42,72-73,75, 東京消 防庁, 2010.

58）東京都港湾局 : 東京都港湾局ホームページ「水門閉鎖情報のメール配信サ ービス」, htpp//www.kouwan_metro.tokyo.jp/jigyottakashio/mail/mailhthml

59）東京都総務局 : 東京都総務局ホームページ「東京都方災ホームページ」， http:/www.bousaimetr.tokyo.jpindex.html

60) 東京都主税局 : 東京都主税局ホームページ「減免・猶予制度」, http://www.tax.meto.tokyo.jpcommon/genmen.html,

61）東京都: 東京都豪雨対策基本方針 平成19年8月，pp29，東京都，2007.

62) 中央防災会議 : 大規模水害対策に関寸る専門調查会報告 平成22年4月, pp.24，中央防㷋会議，2010.

63) 東京都交通局 : 事業概要 平成21年版，pp.78-79, 86-88，東京都交通局，2009. 
64) 東京都建設局 : 東京都建設局ホームページ「過去の水害記録」， http//www.kensetsumetro.tokyo.jp/suigai_kirokukako.htm

65) 国土交通省, 東京都, 神奈川県, 横浜市, 川崎市, 町田市, 稲城市: 鶴見川 流域水害対策計画 平成19年3月, pp.23,26-27，国土交通省，2007.

66) 東京都中央卸売市場 : 東京都中央卸売市場ホームページ「豊洲新市場整備 方針及び施設の概要」，http:/www.Shijoumetro.tokyo.jp/gyosei07/siiyou65/kentou31.pdf

67) 東京都交通局: 東京都交通局経営計画ステップアップ2010 平成22年2月, pp.66-69, 東京都交通局, 2010.

68) 東京都建設局 : 東京都建設局ホームページ「都立公園の整備を推進してい ます」, http//www.kensetsumetro.tokyo.jpkouen/seibiindex.hml

69）東京都建設局 : 東京都建設局ホームページ「街路樹の充案」, http//www.kensetsumetro.tokyo.jpkouen/gaiyo02html

70) 東京都 : 2006 - 2015東京都住宅マスタープラン 平成19年3月, p.33, 東京都, 2007

71) 東京都建設局 : 東京都建設局ホームページ「<東京都土砂災害危険䇢所マ ップ>全体索引図」, htpp//www.kensetsumeto.tokyo.jpkasen/mapSSakuinALLhtml

72) 東京消防庁: 東京消防庁ホームページ「<広報テーマ (2010年7月号) > 熱 中症を防ごう」, http://www.tddmetro.tokyo.jplcamp/2010201007/camp1.hmmlltopic2

73) 東京㴥方庁: 東京消防庁ホームページ「熱中症にご用心!, http:/www.tfdmetro.tokyo.jp/fekyutradvheat_disindex.html

74）東京都: 東京都環境基本計画 平成20年3月，pp.37-42,49,52,54-55,57,82, 東京 都, 2008.

75) 東京都: 東京都感染症予防計画 平成20年3月, pp.2, 6, 8, 10, 12, 東京都, 2008.

76) 東京都: 東京の福祉保健の新展開2010 平成22年2月, pp.68,73, 東京都, 2010.

77) 東京都中央卸売市場 : 事業概要 平成21年版, pp.51,54,74, 東京都中央卸売 市場, 2009 .

78) 東京都環境局 : 東京都環境局ホームページ「東京都の光化学スモッグ注意 報等の発令状況」，htp://www.ox.kankyo.meto.tokyo.jp/smoghm, 2011.3.18

79）東京都環境局 : 東京都環境局ホームページ「大気污染地図情報（速報 值) 」, http//www2.kankyo.metr.tokyo.jpbunpu1/cgil/p101..gi

80) 東京都: 東京都自動車排出空素酸化物及び自動車排出粒子状物質総量削減計 画 平成16年3月, pp.2427, 30, 東京都, 2004.

81) 東京都環境科学研究所 : 東京都環境科学研究所ホームページ「大気環境」, http:/www.tokyokankyo.jpkankyoken/research/aipolltrion/index.htm

82) 東京都産業労働局 : 東京都産業労働局ホームページ「花粉症発生源での森 林整備」，http:/Www.sangyo-rodometro.tokyo.jphoinkafun/seibisseibihtml

83）東京都総務局 : 東京都絵務局ホームページ「平成20年度東京都・中央区・江 東区合同総合防災訓䊅」，

htp://www.bousai.metro.tokyo.jpjapanesetmgttaining_11.html

84) 東京都島しょ農林水産総合センター: 島しょ地域農林水産戦略構想 平成18 年8月, p..10, 東京都島しょ農林水産総合センター, 2006.
85) 東京都: 東京都ホームページ「平成22年度第2回インターネット都政モニタ ーアンケート結果 生物多様性について」, http:/www.metrotokyo.jp/INET/CHOUSA20100960k9d100.hm

86) 東京都: 東京都ホームページ「生物多様性の把握に向けて〜植物標本の収 集と保存〜」，ｈ.tp:/www.metro.tokyo.jpIINET/BOSHU/201006/2k68100.hm

87) 東京都環境局 : 東京都環境局ホームページ「自然・野生動植物の保護」, http:/www.kankyo.metro.tokyo.jpfaqqanimals_plants.html

88) 東京都総務局 : 山間部防災対策行動計画 平成19年3月，pp.21-35，東京都総 務局, 2007.

89) 東京都建設局 : 東京都建設局ホームページ「東京都水防計画」, http:/www.kensetsumetro.tokyo.jpkasen/suiboukeikaku/index.html

90) 東京都産業労働局 : 東京都産業労働局ホームページ「東京発チーム事業継 続」, http://wwwsangyo-rodometro.tokyo.jp/shokokeieiBCP/bppindex.htm

91) 東京都: 都政のBCP (東京都事業継続計画) <地震編> 平成20年11月, pp.15, 東京都, 2008.

92) 東京都福祉保健局健康安全部感染症対策課（編）：東京都感染症マニュアル 2009 平成21年3月, pp.100-113,182-183,190-191，東京都, 2008.

93) 東京都・特別区・市町 : 都市計画公園・緑地の整備方針 平成18年3月, pp.32, 東京都・特別区・市町, 2008 .

94) 東京都福祉保健局 : 東京都福祉保健局ホームページ「感染症予防チェック リスト(学校及び社会福祉施設) 」,

http:/www.fukushihoken.metro.tokyo.jpiryokansen/chetukuisutolindex.html

95) 東京都: 2010東京の福祉保健 平成22年4月, pp.28, 48, 53-56, 65-68, 71, 東 京都, 2010.

96) 東京都: 東京都高齢者保健福祉計画 平成21年3月，pp.13，49-62，116，121122, 東京都, 2009.

97) 東京都: 東京都保健医療計画 平成20年3月，pp.76，87-96，148-149，177-179， 187-190, 197-204, 東京都, 2008.

98) 東京都環境局 : 都内の地下水揚水の実態 (地下水揚水量調查報告書) 平成 22年2月, pp2, 東京都環境局, 2010.

99) 東京都土木技術支援・人材育成センター: 平成21年地盤疒下調查報告書 平 成22年7月，pp.1，東京都土木技術支援・人材育成センター，2010.

100)Environment Agency. Thames Estuary 2100, Managing flood risk through London and the Thamesestuary, Technical Report,2009.

以上，各URLの最終アクセス日は2011.3.30

\title{
INVESTIGATION OF EXISTING POLICIES CONTRIBUTION TO PROMOTING CLIMATE CHANGE ADAPTATION -A CASE STUDY IN TOKYO-
}

\author{
Yasuaki HIJIOKA, Kazutaka OKA, Saneyuki TAKANO, \\ Minoru YOSHIKAWA and Arata ICHIHASHI
}

\begin{abstract}
The impacts of global warming are already appearing in various regions of the world. Therefore, in addition to strongly promoting mitigation policies, it is an urgent need to study and implement adaptation policies from a longterm perspective in preparation for some possible negative impacts. The Japanese Government has long promoted various countermeasures for disaster prevention, environmental management, food production and protection of the nation's health. These countermeasures are considered to have potential effects as climate change adaptation. This study investigated to what extent the existing policies for Tokyo can contribute to its climate change adaptation on the basis of comprehensively organizing targeted fields and indicators in which adaptation policies should be taken. Research results indicated that the existing policies could be useful as climate change adaptation in many fields and indicators. Furthermore, the present problems were clarified accompanied with implementation of climate change adaptation at the municipalities' level, and solutions were proposed on how to use scientific knowledge to solve the problems.
\end{abstract}

